九病虫研会報 $49: 71-76$ (2003)

Kyushu PI. Prot. Res. 49 : 71-76 (2003)

\title{
中国・華南農村における水稲病害虫 とその防除に対する農民の認識
}

\author{
足達 太郎* \\ (東京大学大学院農学生命科学研究科)
}

\begin{abstract}
Farmers' perceptions of pests and diseases of paddy rice and their control in a farming village in southern China. Tarô Adati (Graduate School of Agricultural and Life Sciences, University of Tokyo. Tokyo 113-8657, Japan)
\end{abstract}

Key words : China, farmers' perception, Guangxi Zhuang Autonomous Region, paddy rice, pest and disease control

緒

\section{言}

中国の華南地方は，世界有数の水稲作地带である。 1999年には中国の水稲総生産量は198,487千 tであった が、華南だけでその70\%を生産している（国家統計局， 2000)。1970年代の後半から中国では単位面積あたりの 水稲収量が急激に増加しており(国家総計局, 2000), 特に華南における生産性は国際的にみても高い水準にあ ることが注目される。このような単収の急増は，中国に おけるハイブリッドライスの導入と時期をほほ同じくし ており（天野，1996；Yuan, 1998），ハイブリットライ スが本地域に扔ける生産性增大にはたした役割は大きい と推測される。

ところで，華南が属する亜熱带気候区は，元来，病害 虫による被害が甚大な地域であった。そのため，八イブ リッドライスの作付增にともなう殺虫剤・殺菌剂の使用 量の増加が，同地域に分布する病管虫の薬郕抵抗性やバ イオタイプなどの発達をうながすことが危惧される。近 年, わが国で移動性の重要害虫として知られているイネ ウンカ類の飛来源が, 華南およびベトナム北部であるこ とが明らかにされた（Sogawa，1997a；1997b)。加害性 が遺伝的に制御される害虫個体群が，飛来源でどのよう な人為的環境のもとにあったのかを把握することは，飛 来地であるわが国におけりる害虫管理計画を策定するうえ で重要である。しかしながら，華南に扔ける水稲病害虫 防除の実態を見聞した報告はあまりない。

\section{*現在 国際熱带農業研究所}

*Present address: International Institute of Tropical Agriculture (IITA), Kano Station. Sabo Bakin Zuwo Road, PMB 3112, Kano, Nigeria
一方, 農民が病害虫防除をどのようなやり方・規模で 行なうかについては，さまざまな要因が関与している。 Ortiz (2002) は，途上国に扔けるジャガイモの病害に関 連して，防除遂行の意思決定に影響を㧍よほ正要因とし て, 農生態学的要因, 防除資材の入手可能性, 耕作経験。 病害についての知識と理解が重要であることを指摘して いる。華南の農民たちは, 水稲の病害虫による被害をど のようにとらえ，どのような防除手段を選抧しているの だろうか。そのような農民個人の病害虫防除に対する認 識を明らかにすることは，今後，グローバルかつ持続可 能な農業生産システムを開発するうえで不可欠な課題で ある。

著者は華南の南西部、㕕西チワン族自治区の農村で聞 きとり調查を行ない，水稲作に従事する農民加病害虫 の実態とその防除について彼らの若えを聞く機会を得た。 本稿では調査の結果を提示しながら，特に病害虫防除に 関する知識や実践に对して、農民を取りまく社会的背景 がどのような影響をおよほしているのかを考察した。

\section{調 查 地の概 要}

調查は中国・広西チワン族自治区上林県にある一農村 で、1997年3月8日から17日まで10日間にわたって行 なった。村は雲貴 (ユンコイ) 高原の南東部, 穴西盆地 のほぼ中央に位置する。西江水系の河川が流れる水の豊 かな土地である。平熱带湿潤気候带に属し、夏に雨が多 く，華南農業では典型的な米の二期作が行なわ机ている。 1997 年 3 月現在の村の人口は546人, 戸数は81戸で あった。住民は多数の漢族と少数のチワン（壮）族から なる。土地利用は，水田20ha，サトゥキビ，トウモロ コシ、ラッカセイなどが作付けされる烟地20ha，リュ 
ウガンなどが栽培される果樹園16ha などである。

水稲作は，例年 3 月上旬に 1 期作目（春作）の播種を 行なう。本田への移植は 3 月下旬から 4 月上旬にかけて 行なわれ，7月下旬に収穕される。このあと 2 期作目 (秋作）の播種がすぐに始まり，8月下旬に本田移植，12 月下旬ごろに収穫される。

\section{謂 查の方法}

村で水稻作を行なっている50戸あまりの農家のうち， 42戸を個別に訪問し，家族のなかで実際に耕作に従事し ている人を 1 人選んで䦥きとりを行なった。調査対象と なった人達の民族・性別・年踚の内訳を第 1 表に示した。

第 1 表 話し手の内訳

\begin{tabular}{lrrr}
\hline \multicolumn{1}{c}{ 区分 } & 男 & 多 & 計 \\
\hline 民族 & & & \\
漢族 & 18 & 16 & 34 \\
チワン族 & 1 & 6 & 7 \\
客家 & 0 & 1 & 1 \\
$\quad$ 計 & 19 & 23 & 42 \\
年齢層 & & & \\
$30-39$ & 8 & 8 & 16 \\
$40-49$ & 7 & 10 & 17 \\
$50-59$ & 2 & 4 & 6 \\
$60-69$ & 2 & 1 & 3 \\
計 & 19 & 23 & 42 \\
\hline
\end{tabular}

聞きとりは通訳を介して行なった。村で日常的に用い られている言語は，おもに「土話」と呼ばれる漢語方言 および「壮話」と呼ばれるチワン語であった。村人の何 人かはこの他に「普通話」と呼ばれる漢語標準語も使用 することができた。通訳を担当した助手は，壮話を母語 とし，英語と普通話が使用できたので，普通話および壮 話を英語に通訳した。土話の話者に対しては，普通話を 話せる村人に通訳を依頼し，さらにそれを英語に通訳し た。

聞きとりに際しては，年霜や家族構成，水稲作付面積， 収量などといった、いくつかの定型の質問を用意したが， 質問表のような形で画一的に質問するのではなく，話し 手がなるべく自由な形で回答できるよう心がけた。

調查時は，ちょうど春作の播種を終えたばかりだった ため，水稲病害虫やその防除の現場を実際に観察するこ とはほとんどできなかった。したがって，開きとった病 害虫名を実物で確認することも不可能たっった。そこで, 病害虫の現地呼称からその種類を特定するため, 害虫や 病徵が描かれたカラー図版を話し手に見せた。図版は 「植保員乎冊」《植保員手冊》編絵組，1992）に収録さ れているものを用いた。
結

果

\section{1. 単収の増加とその要因}

まず，各農家で過去と最近の水稲生産量について聞い たところ，1986年の10a 当り年間平均収量（籾重， 2 期 作の合計) は $615 \pm 33 \mathrm{~kg}$ (平均 \pm 標準誤差, サンプル数 38）であったのに対し，1996年には1,250 $27 \mathrm{~kg}$ (サン プル数42）であった。

過去10年ほどの間に単収がこのようにほほ倍增した理 由として, 多くの人が「病害虫防除の実践」「改良品種 の使用」「合理的な施肥」の3つの要因をあげた。一方, 現在の水稲栽培において生産を阻害する要因をたずねた ところ，はとんどの人が「病害虫」(91\%)をあげた。 それに次いで「旱魃」(52\%) 捛よび「肥料の不足」 （35\%）が多かった（第 2 表)。

第 2 表 農民が言及した水稲生産の阻害要因

\begin{tabular}{lcc}
\hline \multicolumn{1}{c}{ 要园 } & 回答数 & 頻度 $(\%)$ \\
\hline 病害虫 & 21 & 91.3 \\
旱魅 & 12 & 52.2 \\
㜆料の不足 & 8 & 34.8 \\
種子の不良 & 3 & 13.0 \\
労傎力の不足 & 3 & 13.0 \\
鼠害 & 2 & 8.7 \\
\hline
\end{tabular}

a) 回答者数 23 名。

\section{2. 病害虫の内訳と防除手段}

水稻を加害する害虫は，ズイムシ類，コブノメイガ， イネウンカ類, カメムシ類, イネノシントメタマバエを あげる人が多かった（第 3 表）。病害のなかではイネ紋 枯病が最も多かった。この他，何人かの人がノネズミに よる被害をあげた。

これらの病害虫（獣）に対する防除手段については， 回答したすべての人が「農薬散布」をあげた（回答者数 42名)。農薬散布以外の防除手段をあげた人は少なかっ たが，過去に行なっていた手段も含めると，「害虫の捕 殺」（8 名），「灯火による誘殺」( 5 名)，「石灰散布」 (5名)，「ノネズミに対するわな」(2名)などがあげら れた。

農民がこれまでに使用したことがある農薬のリストを 第 4 表に示した。この中には現在では使われていないも のも含まれるが，「杀虫双」「甲胺磷」「乐果」など，合計 15品目の殺虫剂，殺菌郕，殺鼠剤があげられた。

\section{3. 病害虫防除に対する認識}

第 4 表や個別の回答から，この村では多種類の有機合 成譨薬が比較的容易に入手され，使用されていることが うかがわれた。農薬の效果について闒いてみると，多く 
第 3 表 農民が言及した水稲病害虫の内訳 ${ }^{a}$

\begin{tabular}{|c|c|c|c|}
\hline 病害虫名 & 現地での㭔称") & 学名 & 回答数 ${ }^{\mathrm{c}}$ \\
\hline ズイムシ類 & 鑽心虫 & (Lepidoptera) & 35 \\
\hline コブノメイガ & 巻叶虫 & $\begin{array}{l}\text { Cnaphalocrocis medinalis } \\
\text { (Lepidoptera: Pyralidae) }\end{array}$ & 31 \\
\hline イネウンカ類 & 稲飛虫 & (Homoptera: Delphacidae) & 29 \\
\hline カメムシ類 & $\begin{array}{l}\text { ngan, 臭屁虫, 稲蝽蟓, } \\
\text { ngankyan, nokek }\end{array}$ & (Hemiptera) & 20 \\
\hline $\begin{array}{l}\text { イネノシントメ } \\
\text { タマバエ }\end{array}$ & 稲瘦蚊 & $\begin{array}{l}\text { Orseolia oryzae } \\
\text { (Diptera: Cecidomyïdae) }\end{array}$ & 18 \\
\hline イネヨトウ & 大蛽 & $\begin{array}{l}\text { Sesamia inferens } \\
\text { (Lepidoptera: Noctuidae) }\end{array}$ & 8 \\
\hline イネ紋枯病 & 紋枯病 & Thanatephorus cucumeris & 8 \\
\hline イネットムシ & 稻苞虫 & $\begin{array}{l}\text { Parnara guttata } \\
\text { (Lepidoptera: Hesperiidae) }\end{array}$ & 6 \\
\hline ノネズミ & 鼠子 & (Rodentia: Muroidea) & 5 \\
\hline サンカメイガ & 三化蛽 & $\begin{array}{l}\text { Scirpophaga incertulus } \\
\text { (Lepidoptera: Pyralidae) }\end{array}$ & 5 \\
\hline $\begin{array}{l}\text { ウンカ・ヨコバイ・ } \\
\text { アザミウマ類など }\end{array}$ & 螨 & (Homoptera, Thysanoptera, etc.) & 5 \\
\hline イネいもち满 & 稲瘟病 & Pyricularia grisea & 3 \\
\hline バッ夕類 & $\begin{array}{l}\text { mongmaa, ngyaan, } \\
\text { 蝗出 }\end{array}$ & (Orthoptera) & 3 \\
\hline イネアザミウマ & 稲薊馬 & $\begin{array}{l}\text { Stenchaetothrips biformis } \\
\text { (Thysanoptera: Thripidae) }\end{array}$ & 2 \\
\hline ガ類 & 飛蛾 & (Lepidoptera) & 2 \\
\hline (不明病害) & 勫条病 & & 2 \\
\hline ヨコバイ類 & 稲叶蝉 & (Homoptera) & 1 \\
\hline ゾウムシ類 & 鉄甲虫 & (Coleoptera: Curculionoidea) & 1 \\
\hline
\end{tabular}

a）病害虫名は「植保員手册」（1992）の図版を参照した。分類は回答者による呼称に基づいたため。「螨」（ウンカ・ヨコバ イ・アザミウマなどの小型で飛び跳极る出）や「飛蛾」(ガ類) など，分類の曖昧なものや大まかなものがある。

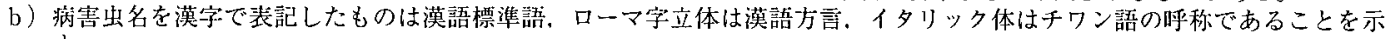
†。

c) 回答者数 40 名。

の農民に共通する答えは「もしも殺虫郕を使わなければ， 害虫が大発生して収穫が減る」というものであった。市 る農民は「今の農薬はとても効果があるので，他の防除 法を行なう必要はない」(チワン族，女，44歳）といっ て農薬の防除効果を全面的に評価した。しかし一方では, 「農薬は健康に良くない。現に農薬のせいで頭痛になり， 寝こんでいる人が村に 2,3 人いる。(害虫の天敵とな る）益虫を利用するのが良いが，数が多くないので効果 は少ない。しかし，農薬をまったく使わないと収量が 隇ってしまうので，使わないわけにはいかない」(チワ ン族，男，62歳）という農薬の使用をめぐるジレンマに ついて語る人もいた。

害虫防除の手段として天敵の利用をあげる人は少な かった（42名中 1 名）。それでも，どんな天敵を知って いるかと聞くと，かなり多くの種類があげられた。最も
多かったのは「トノサマガエル」で，全回答者42名のう ち39名があげた。ついで「へビ」(18名)，「ッバメ」(16 名)，「フタロウ」(11名)，「夕力」(7名)，「コウモリ」 （5名）などがあげられた。このうちへビ，フクロウ， タカはノネズミの天敵としてあげたものと思われる。節 足動物の天敵では，わずかにトンボ（4名）とカマキリ （1名）があげられた。「クモは益虫か？」とたずねると， 多くの人は「半分害虫, 半分益虫」と答えた。「クモは 害虫も捕食するが，稲の菜に網をかけて生育を阻害する ため, 水田内で見かけたら取り除く」(漢族, 男, 37葴) のだという。 
第 4 表 使用したことがある農泟とその標的

\begin{tabular}{|c|c|c|c|c|}
\hline 震薬名 & 一般名" & 分 類 ${ }^{b}$ & 標的病夆贵 & 回答数" \\
\hline 杀虫双 & dimehypo & ネライストキシン系殺虫䍑 & $\begin{array}{l}\text { ズイムシ類，コブノメイガ，サンカメイガ， } \\
\text { イネアザミウマ }\end{array}$ & 30 \\
\hline 甲胺磷 & methamidophos & 有機リン系殺虫拜 & $\begin{array}{l}\text { ズイムシ類. コブノメイガ, イネウンカ類, } \\
\text { カメムシ類, イネアザミウマ }\end{array}$ & 25 \\
\hline 乐果 & dimetoate & 有機リン系殺出郕 & イネウンカ類，カメムシ類，イネアザミウマ & 17 \\
\hline 敌百虫 & trichlorphon & 有㙨リン系秌出剂 & $\begin{array}{l}\text { ズイムシ類, コブノメイガ, イネットムシ， } \\
\text { イネアザミウマ }\end{array}$ & 13 \\
\hline 敌敌带 & dichlorvos & 有僟リン系殺地㜄 & イネウンカ類, カメムシ類 & 13 \\
\hline 呋喃丹 & carbofuran & カーバメート系殺虫㣚 & イネノシントメタマバエ & 10 \\
\hline 杀虫㜆 & chlordimeform & 除虫版 & ズイムシ䊁, コブノメイガ, イネアザミウマ & 9 \\
\hline 甲基异柳磷 & isofenphos methyl & 有機リン系殺虫削 & イネノシントメタマバエ & 9 \\
\hline 三唑磷 & triazophos & 有機りン系殺虫片 & ズイムシ類，コブノメイガ，イネアザミウマ & 7 \\
\hline 敌鼠钠盐 & (不明) & 殺鼠片 & ノネズミ & 6 \\
\hline 偂戊菊酯 & fenvalerate & ピレスロイド系殺虫剂 & カメムシ類 & 5 \\
\hline 扑奥灾 & buprofezin & 䀝出成辰制御珮 & イネウンカ類，力メムシ類 & 5 \\
\hline 井网霉素 & Jinggangmycin & 抗生物質殺菌剂 & イネ紋佔病 & 4 \\
\hline 叶蝉散 & isoprocarb (MIPC) & カーバメート系殺出剂 & イネウンカ類 & 3 \\
\hline 磷化锌 & zinc phosphide & 殺鼠绪 & ノネズミ & 2 \\
\hline
\end{tabular}

a）農薬の一般名は「植保員手冊」（1992）その他を参考にした。

b) 農薬の分稹は「㖘涾ハンドブック2001年版」その他を参考にした。

c) 回答者数 31 名。

\section{考察}

\section{1．社会的背景が病害虫防除の知識と実践におよぼす 影響}

ここまで，蜄民の病害虫とその防除に対する認識抢よ び実践を各個人のレベルで見てきたが、ではそのような 認識や実践は，はたして農民個人の生得的な薏思に基づ いてなされたものであろうか。そうでないことは，病害 虫防除上いう行為が，個人の経験や知識に加之て，その ような知識・経験を得るための社会的背景やさまざまな 情報の得やすさに大きく依存していることからも明らか である。

そこで，具体的にどういった社会的要䋕が病害虫防除 に関する知識や意思決定に影管をおよばしているのかを 明確にするため，閏きとりで得られたデー夕に基づき， 農民が名前を知っている病害出の数および使用したこと がある農薬の品目数と，民族・性別・年齢・就学年数・ 水稻耕作面積との相関をそれぞれ調べた。その結果，使 用したことがある農薬の品目数と民族の別，知っている 病害虫の数と耕作面積の閒にそれぞれ有意な相関が認め られた（第 5 表，第 1 四)。

第 5 表に示したとおり，漢族の農民が使用したことの ある農薬の品目数は，チワン族啀民よりも顕著に多かっ
第 5 表 使用したことがある農藥の品目数（民族別）

\begin{tabular}{lcc}
\hline 民族 & サンプル数 & 中央值 (範囲) \\
\hline 漢族 & 28 & $5 \mathrm{a}(0-9)$ \\
客家 & 1 & $3 \mathrm{ab}$ \\
チワン族 & 5 & $2 \mathrm{~b}(0-4)$ \\
\hline
\end{tabular}

a) Kruskal－Wallisの検定により，垬なる民族の閶で有意差 があった（ $p<0.05 ）$ 。同じ文字の付いた数估は，ノンパ ラメトリックなTukey - type の多重比㛺により，且いに 有意差がないこと（ $p>0.05\rangle$ を示す。

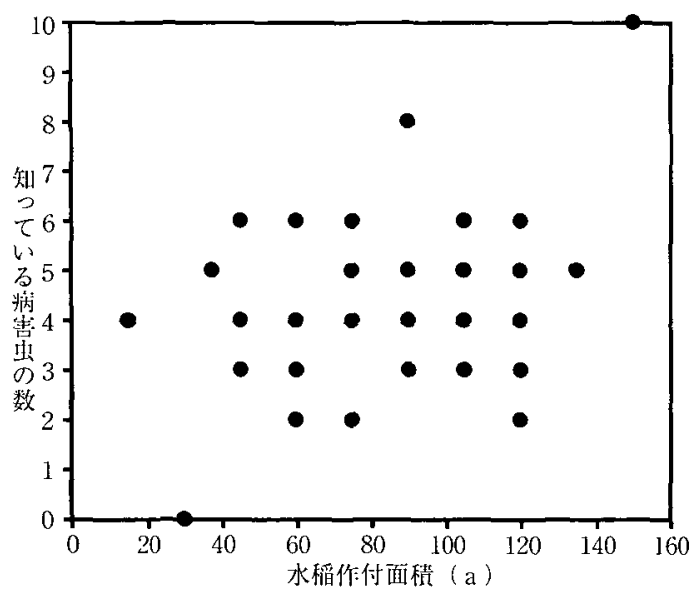

第 1 図 备農民の水稻作付面積と知っている病害虫数 の相関

Kendall $の$ 順位相米係数 $\tau=0.217, p<0.05$ で有稳な 相関があった。 
た。農薬の使用に関して両民族の間でなぜこのような違 いがあるのか, 正確な理由はわからないが，一つには言 語の問題があると思われる。農薬の製造・販壳は中国で はもっぱら漢民族によって行なわれており，購買層もお もに多数民族である漢民族が想定されているものと推測 される。このことは第 4 表に示した漢語由来の㷧薬名に も現れている。少数民族であるチワン族にとっては，農 薬というものは異文化である漢語文化圈からもたらされ る文物であるといえよう。実際問題として，使用法や新 製品の紹介などといった場面における情報入手の可能性 の差は，両民族の間で少なくないと思われる。このよう な差異が，彼らの農薬使用に対する取りくみ方の違いに つながっているのではないだろうか。

第 1 図は, 各嘅民の水稲作付面積と知っている病害虫 の種類数が有意な相関をもつこと、すなわち作付面積が 広いほどより多くの病害虫を知っている傾向があること を示している。このような傾向には，知っている病害虫 の数というのは一種の経験値であり,より㕕い面積を耕 作するほど, 経莬を積んで病害虫に関する知識がふえる という解釈が可能である。しかし一方で，たとえ耕作面 積がふえても，単純な作業経験からだけでは病害虫の知 識はそれほど多くは得られない可能性もある。中国の農 村では一般に，土地は村が所有しており，農民は村から 耕作を請け負うことによって農業生産に従事している (阿古，2003)。調查した村においては，水田面積の請負 権は家族の人数に芯じて定められていた。この場合, 家 族の人数には出稼きや就学のため村外に出ている者も含 まれるのであるが，笑際の耕作面積は，農作業のための

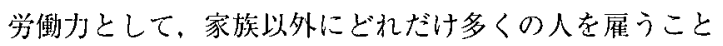
ができるかにかかっているようだった。こうしてみると， 病害虫についての知識は耕作の経験によって受動的に蓄 積されたのではなくて，より大規模な水稲作農業を経営 してゆくために必要不可久な知識として積極的に獲得さ れたという解釈も成り立つであろう。以上のような仮説 を検証するためには、より詳細な社会経済学的調查が必 要である。

\section{2. 病害虫とその防除についての知識の情報源}

それでは, 病害虫についての知識は，どのようにして 農民にもたらされるのであろうか。病害虫とその防除に ついての聞きとりを進めてゆくうちに，農民たちの話題 にある共通の言葉が浮かび上がってきた。例をあげると， ある人に害虫の名前をたずねたところ，「私はいつも改 良士の指示にしたがって，決まった時期に農薬を散布す るだけなので、害虫の名前など拈ぼえる必要はない」と いう答えがあった。また別の農民は、「改良所から農業
士が村に来て, 彼から病害虫の防除法を習った」という。 あるいはまた，「私は農業老師から改良種子や㱖薬を 買っている。彼女は村にやって来て, 農薬の使い方など, いろいろな農業技術について教えてくれる」という話も あった。

これらの話のなかで共通しているのが、「農業老師」 という存在である。これは「改良士」「農業士」「農技 員」などという名前で呼ばれる人びとを一括したもので ある。日本に扔ける「普及員」に近いもののようだが， 調查期間中にこのような人涬と接触することはできな かった。村人達の話を総合すると，「農業老師」にはそ の所属や身分などから，(1)農業試験場や改良普及所など の公的機関の職員，(2)種子会社や辳䕓会社などの普及・ 販壳員, (3)村人で試験場や普及所の元職員という3つの ケースがあることがわかった。今後，行政もしくは会社 組織による病害虫の防除技術や知識の普及および農薬の 流通について、この「農業老師」がどのような役割をは たしているのか，さらに詳しく検討する必要がある。

\section{摘 要}

1997年 3 月に中国・広西チワン族自治区の一農村にお いて、水稲病害虫とその防除に対する農民の認識を調心゙ ることを目的に、万別に閆きとり調查を行なった。

1. 水稲収量が近年急堌した要因として, 多くの農民が 「合理的な施肥」「改良品種の使用」とともに「病害虫防 除の奏践」をあげた。病害虫は水稲生産の阻害要因とし て最も重要であると認識されていた。

2. 農民が言及した病害虫の内訳は，ズイムシ類、コブ ノメイガ, イネウンカ類, カメムシ類, イネノシントメ タマバエ，イネ紋枯病などが多かっだ。

3. 現在行なっている病害虫防除の手段として，回答者 のすべてが「農薬散布」をあげた。農民がこれまでに使 用したことがある農薬の種類の合計は, 殺虫剂 12 品目, 殺鼠剂 2 品目, 殺菌片 1 品目であった。

4. 農薬の悪影響や天敵の有効性を指摘する農民も存在 するものの，増収のためには農薬の使用は不可欠と考え ている農民が多かった。

5. 使用したことがある農薬の品目数は，漢族農民のは うがチワン族農民よりも影著に多かった。また，各農民 が知っている病害虫の種類数と耕作面積との間には有意 な相関がみら扎た。このような相関は言語文化や資本力 といった社会的背景に根ざしていることが示唆された。

6. 農民の病害虫とその防除手段に関する知識は，「農 業老師」などと呼ばれる試娩・普及機関の職員および元 職員や種子・農薬会社の販売員によっておもにもたらさ 
れているらしい。

\section{引用 文 献}

阿古智子（2003）中国農村の土地制度に関する諸問題と 改革の動向．国際農林業協力 25（10）:37-50. 天野高久（1996）中国に扔ける超多収稲作をめぐって。 農耕の技術と文化 19：67-91.

国家統計局（2000）中国統計年鑑2000. 中国統計出版社 (北京), pp. 888 .

農薬ハンドブック2001年版編集委員会（2001）農薬ハン ドブック 2001 年版. 日本植物防疫協会 (東京), pp. 928.

Ortiz, O. (2002) Teaching farmers IPM in developing countries. In : Late Blight: Managing the Global Threat. Proceedings of the Global Initiative on Late Blight Conference, 11-13 July 2002, Hamburg, Germany. International Potato Center (Lima), pp. 98 $-103$.

Sogawa, K. (1997a) Overseas immigration of rice planthoppers into Japan and associated meteorological systems. In : Proceedings of ChinaJapan Joint Workshop on Migration and Management of Insect Pests of Rice in Monsoon Asia, 27-29 November 1997. China National Rice Research Institute (Hangzhou), pp. 13-35.

Sogawa. K. (1997b) The monsoon-dependent migrations of rice planthoppers in East Asia. In : Proceedings of China-Japan Joint Workshop on Migration and Management of Insect Pests of Rice in Monsoon Asia, 27-29 November 1997. China National Rice Research Institute (Hangzhou), pp. 217-230.

《植保員手冊》編絵組（1992）植保員手冊, 第 2 版. 上 海科学技術出版社 (上海), pp. 429 .

Yuan L.P. (1998) Hybrid rice breeding in China. In : Advances in Hybrid Rice Technology (Virmani S. S., E. A. Siddiq, and K. Muralidharan eds.). International Rice Research Institute (Manila), pp. 27-33.

(2003年 4 月 30 日受領； 6 月17日受理) 